\title{
Bedrock Geology and Hydrostratigraphy of the Edwards and Trinity Aquifers Within the Driftwood and Wimberley 7.5-Minute Quadrangles, Hays and Comal Counties, Texas
}

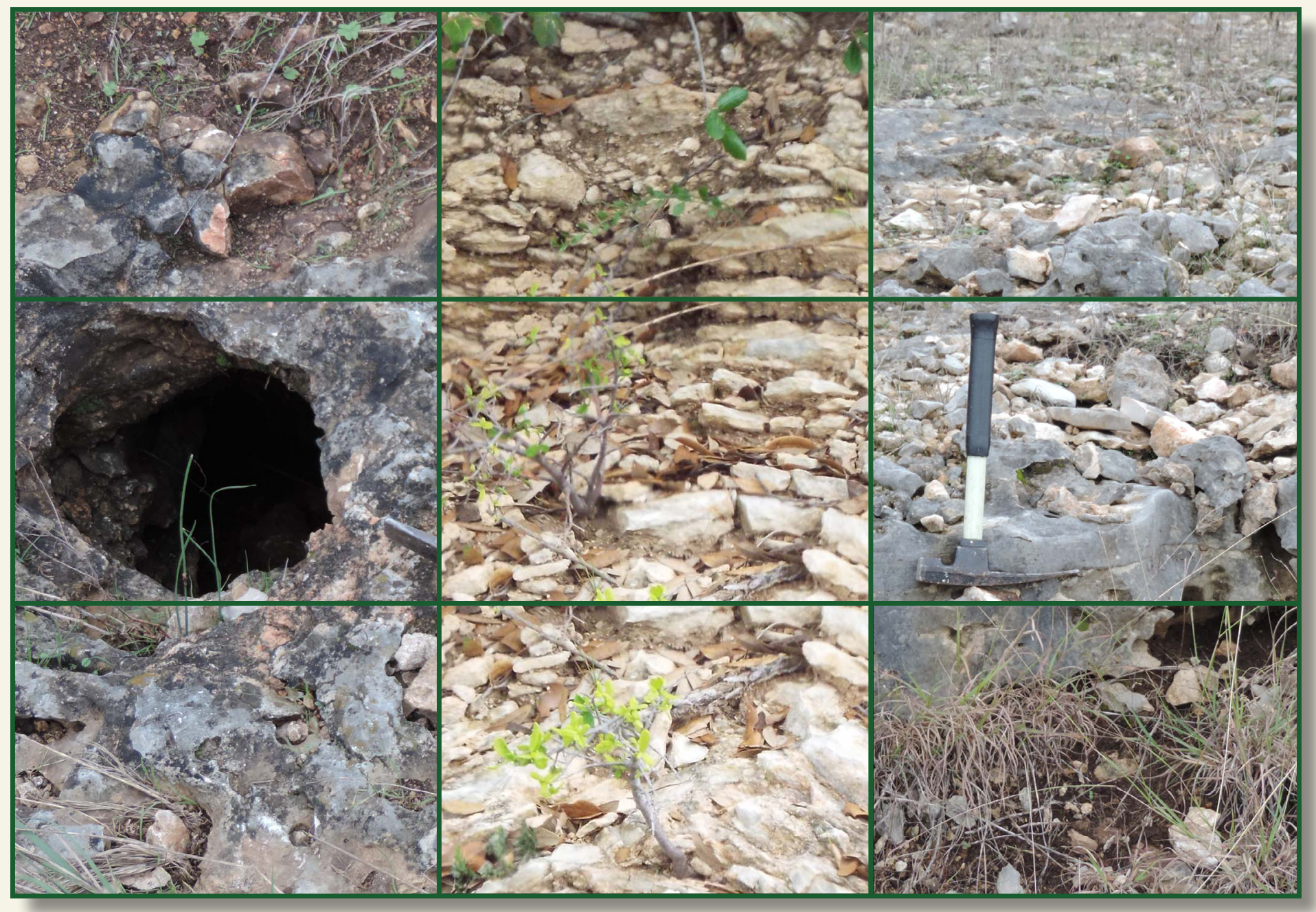

Pamphlet to accompany

Scientific Investigations Map 3386

U.S. Department of the Interior

U.S. Geological Survey 



\section{Bedrock Geology and Hydrostratigraphy of the Edwards and Trinity Aquifers Within the Driftwood and Wimberley 7.5-Minute Quadrangles, Hays and Comal Counties, Texas}

By Allan K. Clark and Robert R. Morris

Pamphlet to accompany

Scientific Investigations Map 3386 


\title{
U.S. Department of the Interior \\ RYAN K. ZINKE, Secretary
}

\section{U.S. Geological Survey William H. Werkheiser, Acting Director}

\author{
U.S. Geological Survey, Reston, Virginia: 2017
}

For more information on the USGS - the Federal source for science about the Earth, its natural and living resources, natural hazards, and the environment-visit https://www.usgs.gov or call 1-888-ASK-USGS.

For an overview of USGS information products, including maps, imagery, and publications, visit https://store.usgs.gov.

Any use of trade, firm, or product names is for descriptive purposes only and does not imply endorsement by the U.S. Government.

Although this information product, for the most part, is in the public domain, it also may contain copyrighted materials as noted in the text. Permission to reproduce copyrighted items must be secured from the copyright owner.

Suggested citation:

Clark, A.K., and Morris, R.R., 2017, Bedrock geology and hydrostratigraphy of the Edwards and Trinity aquifers within the Driftwood and Wimberley 7.5-minute quadrangles, Hays and Comal Counties, Texas: U.S. Geological Survey Scientific Investigations Map 3386, 12 p., 1 sheet, scale 1:24,000, https://doi.org/10.3133/sim3386.

ScienceBase citation:

Clark, A.K., Pedraza, D.E., and Morris, R.R., 2017, Data release of the bedrock geology and hydrostratigraphy of the Edwards and Trinity aquifers within the Driftwood and Wimberley 7.5-minute quadrangles, Hays and Comal Counties, Texas: U.S. Geological Survey data release, https://doi.org/10.5066/F76D5RX0.

ISSN 2329-132X (online) 


\section{Contents}

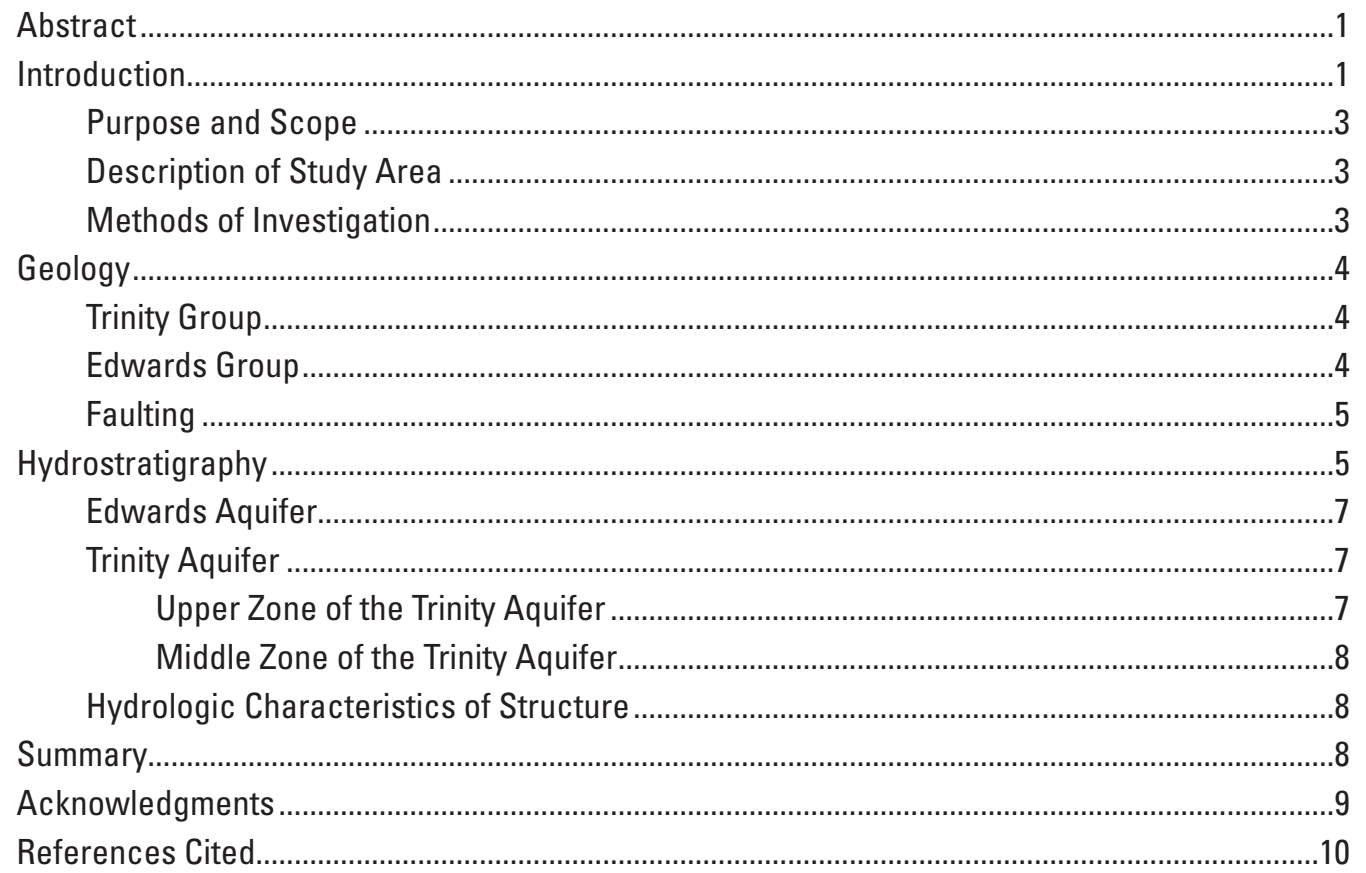

\section{Sheet}

1. Bedrock geology and hydrostratigraphy of the Edwards and Trinity aquifers within the Driftwood and Wimberley 7.5-minute quadrangles, Hays and Comal Counties, Texas

\section{Figures}

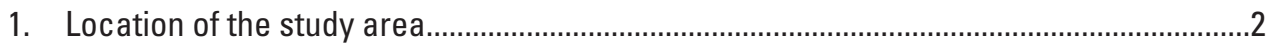

2. Photograph showing rudist in the basal nodular member of the Kainer Formation ..........3

3. Photograph showing chert nodules in the dolomitic member of the Kainer Formation...6

4. Photograph showing laminations in the grainstone member of the Kainer Formation, some fenestral porosity near the top of the boulder ........................................................6

5. Photograph showing solution channels in the hydrostratigraphic units VIII (basal nodular member/Walnut Clay)

6. Photograph of tepee structures at the base of the fossiliferous hydrostratigraphic units. 


\section{Table}

1. Summary of the geologic framework, hydrostratigraphy, ichnology, of the Edwards and Trinity aquifers in the Driftwood and Wimberley 7.5-minute quadrangles in Hays and Comal Counties, Tex

\section{Conversion Factors}

International System of Units to Inch/Pound

\begin{tabular}{lcl}
\hline \multicolumn{1}{c}{ Multiply } & By & To obtain \\
\hline meter $(\mathrm{m})$ & Length & \\
kilometer $(\mathrm{km})$ & 3.281 & foot $(\mathrm{ft})$ \\
& 0.6214 & mile $(\mathrm{mi})$ \\
\hline square kilometer $\left(\mathrm{km}^{2}\right)$ & Area & square mile $\left(\mathrm{mi}^{2}\right)$ \\
\hline
\end{tabular}

Inch/Pound to International System of Units

\begin{tabular}{|c|c|c|}
\hline Multiply & By & To obtain \\
\hline \multicolumn{3}{|c|}{ Length } \\
\hline foot $(\mathrm{ft})$ & 0.3048 & meter $(\mathrm{m})$ \\
\hline mile (mi) & 1.609 & kilometer $(\mathrm{km})$ \\
\hline \multicolumn{3}{|c|}{ Area } \\
\hline square mile $\left(\mathrm{mi}^{2}\right)$ & 2.590 & square kilometer $\left(\mathrm{km}^{2}\right)$ \\
\hline
\end{tabular}

\section{Datum}

Vertical coordinate information is referenced to the North American Vertical Datum of 1988 (NAVD 88).

Horizontal coordinate information is referenced to the North American Datum of 1983 (NAD 83).

Altitude, as used in this report, refers to distance above the vertical datum. 


\title{
Bedrock Geology and Hydrostratigraphy of the Edwards and Trinity Aquifers Within the Driftwood and Wimberley 7.5-Minute Quadrangles, Hays and Comal Counties, Texas
}

\author{
By Allan K. Clark and Robert R. Morris
}

\section{Abstract}

The Edwards and Trinity aquifers are major sources of water in south-central Texas and are both classified as major aquifers by the State of Texas. The population in Hays and Comal Counties is rapidly growing, increasing demands on the area's water resources. To help effectively manage the water resources in the area, refined maps and descriptions of the geologic structures and hydrostratigraphic units of the aquifers are needed. This report presents the detailed 1:24,000-scale bedrock hydrostratigraphic map as well as names and descriptions of the geologic and hydrostratigraphic units of the Driftwood and Wimberley 7.5-minute quadrangles in Hays and Comal Counties, Texas.

Hydrostratigraphically, the rocks exposed in the study area represent a section of the upper confining unit to the Edwards aquifer, the Edwards aquifer, the upper zone of the Trinity aquifer, and the middle zone of the Trinity aquifer. In the study area, the Edwards aquifer is composed of the Georgetown Formation and the rocks forming the Edwards Group. The Trinity aquifer is composed of the rocks forming the Trinity Group. The Edwards and Trinity aquifers are karstic with high secondary porosity along bedding and fractures. The Del Rio Clay is a confining unit above the Edwards aquifer and does not supply appreciable amounts of water to wells in the study area.

The hydrologic connection between the Edwards and Trinity aquifers and the various hydrostratigraphic units is complex because the aquifer system is a combination of the original Cretaceous depositional environment, bioturbation, primary and secondary porosity, diagenesis, and fracturing of the area from Miocene faulting. All of these factors have resulted in development of modified porosity, permeability, and transmissivity within and between the aquifers. Faulting produced highly fractured areas which allowed for rapid infiltration of water and subsequently formed solutionally enhanced fractures, bedding planes, channels, and caves that are highly permeable and transmissive. Because of faulting the juxtaposition of the aquifers and hydrostratigraphic units has resulted in areas of interconnectedness between the Edwards and Trinity aquifers and the various hydrostratigraphic units that form the aquifers.

\section{Introduction}

The Edwards and Trinity aquifers (fig. 1) are major sources of water in south-central Texas (Kuniansky and Ardis, 2004) and are both classified as major aquifers by the State of Texas (George and others, 2011). The population of the central Texas area in Hays and Comal Counties is rapidly growing, increasing demands on the area's water resources (U.S. Census Bureau, 2016). To effectively manage the water resources in the area, detailed maps and descriptions of the geologic structures and hydrostratigraphic units (HSUs) of the aquifers in Hays and Comal Counties, Tex., are needed. Groundwater flow and storage in the Edwards and Trinity aquifers are largely controlled by the aquifers' structure and hydrostratigraphy, and therefore, refined information about these features can help in anticipating and mitigating issues related to changing land use and increasing groundwater demands. In 2016, the U.S. Geological Survey (USGS) mapped the bedrock geology and hydrostratigraphy of the Edwards and Trinity aquifers within the Driftwood and Wimberley 7.5-minute quadrangles in Hays and Comal Counties, Tex. Descriptions of the bedrock geology and HSUs used in this report are modified from those of Clark and others (2016).

The karstic geologic setting of Hays and Comal Counties underscores the need for updated hydrostratigraphic information. For example, the dissolution of the carbonate rocks composing the Edwards and Trinity aquifers results in distinctive landforms rich in both springs and karst features (caves, sinkholes, and other visible areas of solution-enlarged porosity). Porosity developed in carbonate rocks can have an appreciable effect on the hydrostratigraphic characteristics of the formations and can create focused points of recharge (caves and sinkholes) and discharge (seeps and springs) (Hanson and Small, 1995; U.S. Geological Survey, 2011). The same porosity that can focus recharge can also result in an aquifer that is highly susceptible to contamination because storm-water runoff is quickly transferred to the subsurface (Ryan and Meiman, 1996). 


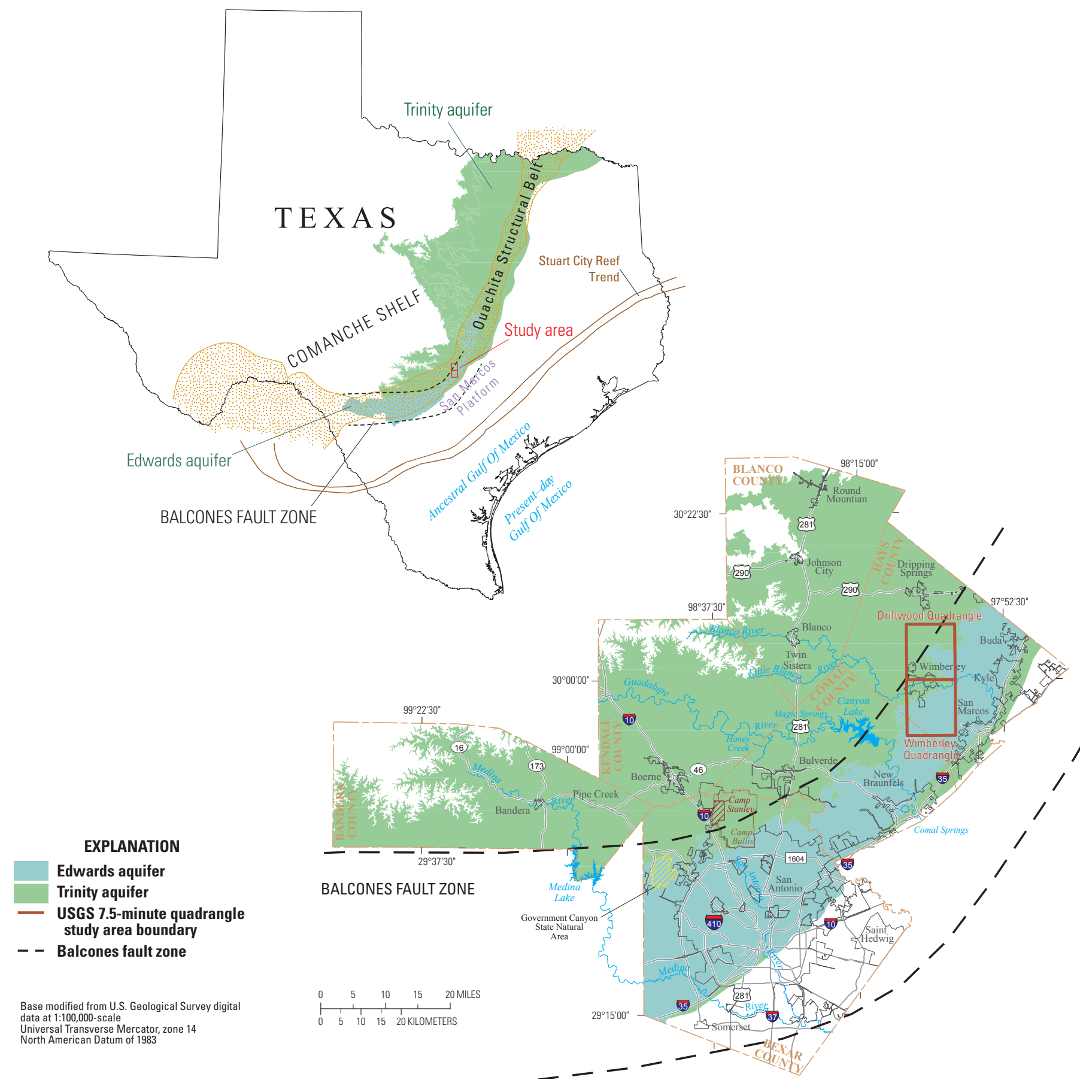

Figure 1. Location of the study area. 


\section{Purpose and Scope}

The purpose of this report is to present the bedrock geology and hydrostratigraphy of the Edwards and Trinity aquifers within the Driftwood and Wimberley 7.5-minute quadrangles in Hays and Comal Counties, Tex. The hydrostratigraphic units were mapped to help improve the understanding of groundwater recharge, discharge, and groundwater flowpaths. The scope of the report is focused on bedrock geology and hydrostratigraphy of the Edwards and Trinity aquifers within the Driftwood and Wimberley 7.5-minute quadrangles in Hays and Comal Counties, Tex. (fig. 1). This report presents the detailed 1:24,000 hydrostratigraphic map as well as names and descriptions of the bedrock geologic and hydrostratigraphic units in the study area. The boundary of the study area coincides with the quadrangle boundaries (fig.1).

\section{Description of Study Area}

The rocks within the approximately 128 square mile $\left(\mathrm{mi}^{2}\right)$ study area are sedimentary and karstic and range in age from Early to Late Cretaceous. Karstic areas are characterized by sinkholes, caves, and underground streams that result in rapid infiltration of surface waters to the subsurface and rapidly flowing groundwater through entrenched paths. Lower Cretaceous rocks form the Trinity and Edwards Groups, and Upper Cretaceous rocks form the Georgetown and Del Rio Formations of the Washita Group (Barker and Ardis, 1996) (fig. 2). The
Miocene age Balcones fault zone is the primary structural feature within the study area. The fault zone is an extensional system of faults that generally trends southwest to northeast in south-central Texas. The faults are vertical to near-vertical with normal throw, are en echelon, and are mostly downthrown to the southeast (Hill, 1900; Maclay and Small, 1986).

\section{Methods of Investigation}

The methods used in this study were similar to those used in Hanson and Small (1995), Stein and Ozuna (1995), Clark (2003, 2004), Clark and others (2009, 2016), and Clark and Morris (2015). Geological data and previous reports were reviewed to assist in field mapping. During 2016, geologic and hydrostratigraphic mapping was carried out in Hays and Comal Counties, Tex., on public and private land. Field mapping was aided by the use of global positioning system (GPS) units, tablet-based digital maps, and geologic mapping applications. Observations were recorded on-site using a tablet computer loaded with geospatially registered 7.5-minute USGS topographic maps. Locations of visible contacts, faults and fractures, marker beds, and other areas of interest were recorded using the integrated $3 \mathrm{G}$-assisted GPS on the tablet computer. Faults identified in the field were based on observed and inferred stratigraphic offsets. Strikes and dips of faults and fractures also were also noted where possible. Bedding attitudes of fractures and faults were obtained using a handheld compass or the tablet-computer compass application.

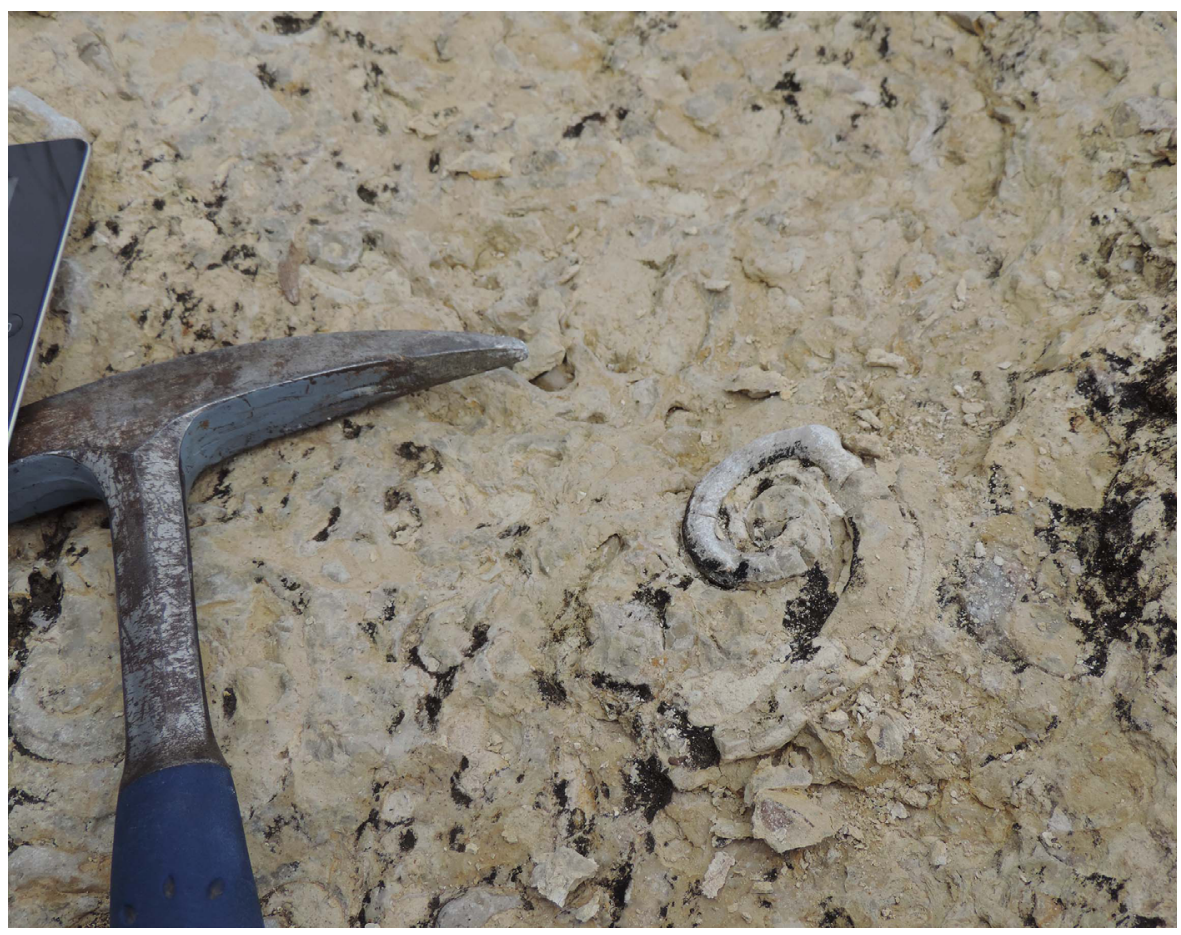

Figure 2. Photograph showing rudist in the basal nodular member of the Kainer Formation. 
Lidar and digital elevation model (DEM) data were used to try to determine the location of sinkholes and springs but neither method supplied reliable location data. Therefore the locations of springs and sinkholes were obtained from field mapping, topographic maps, and the previous geologic mapping report produced by Hanson and Small (1995). Data obtained by the use of the tablet-computer compass application were cross-verified on a regular basis with data obtained with the handheld compass. The field data were transferred using ArcGIS ArcMap version 10.3.1 (Esri, 2016), quality checked by comparison with original draft maps, and then used to develop the geologic and hydrostratigraphic map of the study area.

The descriptions of the bedrock geology and hydrostratigraphy in this report were adapted for the study area from Clark and Morris (2015) and Clark and others (2016). Formal geologic names are consistent with those in the U.S. Geological Survey National Geologic Map Database (U.S. Geological Survey, 2016). Informal geologic and hydrostratigraphic names are consistent with those used in previous publications (Maclay and Small, 1976; Clark and others, 2009; Clark and others, 2014, 2016).

Lithologic descriptions follow the classification system of Dunham (1962) and porosity descriptions are based on the sedimentary carbonate classification system of Choquette and Pray (1970). Thicknesses used in this report are from field observations in the study area. Thickness variations within a unit result from differences in local depositional and erosional conditions. Porosity varies in each lithostratigraphic unit and is dependent on the unit's original depositional environment, lithology, structural history, and diagenesis. HSUs were identified as either fabric-selective or not-fabric-selective based on variations in the amount and type of porosity visually evident in the outcrop. Sedimentological features, paleontology, and ichnofossils (Hantzschel, 1962) were examined and described on site. Ichnofossils were described using morphology, surface textures, and type of burrow-fill (for example, Pemberton and Frey, 1982; Hasiotis and Mitchell, 1993).

\section{Geology}

The Trinity Group (Imlay, 1940) rocks were deposited during the Early Cretaceous on a large, shallow-marine carbonate platform (Comanche shelf) (fig. 1), as clastic-carbonate "couplets" during three marine transgressional events (Lozo and Stricklin, 1956; Stricklin and others, 1971). These three distinct "couplets" deposited sediments that formed (1) the Hosston and Sligo Formations (Imlay, 1940); (2) the Hammett Shale (Lozo and Stricklin, 1956) and the Cow Creek Limestone (Hill, 1901); and (3) the Hensell Sand (Hill, 1901) as well as the lower and upper members of the Glen Rose Limestone (Hill, 1891) which are the focus of this report. The Hosston, Sligo, Hammett Shale, Cow Creek Limestone, and Hensell Sand of the Trinity Group are not present in surface exposures in the study area.
The Lower Cretaceous Edwards Group (Rose, 1972) rocks were deposited in an open marine to supratidal flats environment (Rose, 1972; Maclay and Small, 1986) during two marine transgressions. The rocks that compose the Edwards Group were deposited on the landward margin of the Comanche shelf, which was sheltered from storm waves and deep ocean currents by the Stuart City reef trend in the ancestral Gulf of Mexico (Clark and others, 2006) (fig. 1).

Following tectonic uplift, subaerial exposure, and erosion near the end of the Early Cretaceous, south-central Texas was again submerged during the Late Cretaceous by a marine transgression that resulted in deposition of the Georgetown Formation of the Washita Group (Richardson, 1904). Much of the Georgetown Formation was subsequently removed during a period of marine regression. The Stuart City reef was then breached during a subsequent transgressive episode resulting in deposition of the Del Rio Clay of the Washita Group that continued through the deposition of the Buda Limestone (not present in the study area) of the Washita Group.

\section{Trinity Group}

The Trinity Group contains shale, mudstone to grainstone, boundstone, evaporites, sandstone, and argillaceous limestone and in this study area is represented by the Hosston Formation, Sligo Formation, Hammett Shale (Lozo and Stricklin, 1956), Cow Creek Limestone, Hensell Sand (Barnes, 1976), and Glen Rose Limestone (table 1). The Hosston, Sligo, Hammett Shale, Cow Creek Limestone, and Hensell Sand of the Trinity Group are not present in surface exposures in the study area, and subsequently, will not be discussed further in this report. In the study area, the lower member of the Glen Rose Limestone is typically about 195 feet (ft) thick. The lower member is formed by (least abundant to most abundant) evaporites, miliolid grainstone, shale, boundstone, mudstone to grainstone, and argillaceous wackestone to packstone (table 1). The upper member of the Glen Rose Limestone is typically about $400 \mathrm{ft}$ thick. The upper member is made up of evaporites, mudstone to packstone, miliolid grainstone, and argillaceous limestone. Descriptions of each of the geologic units and their associated lithology and ichnofossils are shown in table 1. For additional geologic and ichnofossil descriptions, see Clark and others (2016).

\section{Edwards Group}

The Edwards Group, which overlies the Trinity Group, is composed of shale, dolomite, chert, evaporites, packstone, grainstone, miliolid grainstone, wackestone, and mudstone. In the study area, the Edwards Group is composed of the Kainer and Person Formations. The Kainer Formation is subdivided into the following informal (bottom to top): the basal nodular (figs.2 and 3) (Walnut Clay [Hill, 1891]), dolomitic (fig. 4), Kirschberg evaporite, and grainstone (fig. 5) (Rose, 1972; Maclay and Small, 1976). Although there is disagreement between various authors on the exact area for the transition of 
Table 1. Summary of the geologic framework, hydrostratigraphy, ichnology, of the Edwards and Trinity aquifers in the Driftwood and Wimberley 7.5-minute quadrangles in Hays and Comal Counties, Tex. (Click here to access a full-size, high-resolution image).

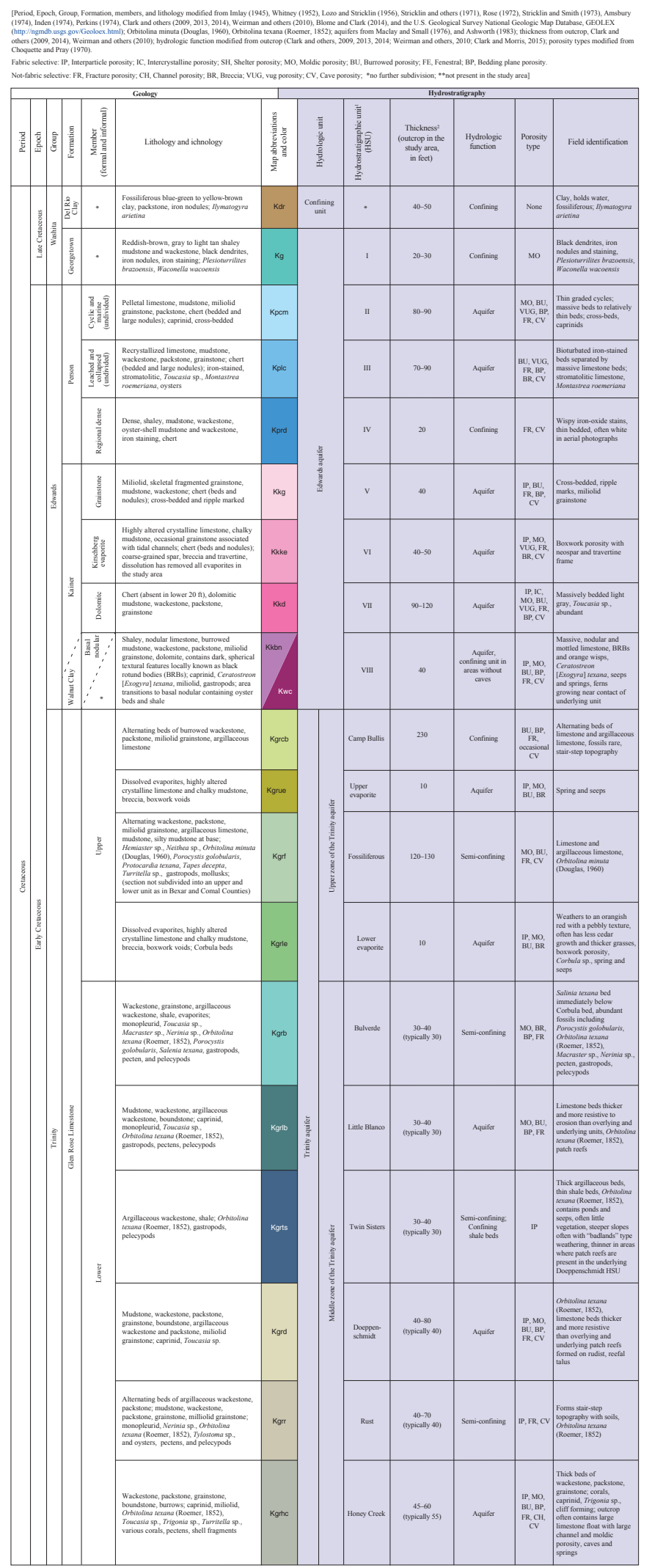

the basal nodular member into the Walnut Clay. Based on field observations, the basal nodular member to the south of the study area is primarily a shaley, nodular, burrowed mudstone to grainstone with dolomite (table 1). In the study area, the basal nodular begins to contain interspersed shale, clay, and oyster (Ceratosteon texana) beds. This change in lithology, which occurs north of Farm to Market Road 32, is considered by the authors to be the area of transition between the basal nodular and Walnut Clay. The Person Formation is subdivided into three informal units (bottom to top): (1) the regional dense, (2) leached and collapsed (undivided), and (3) cyclic and marine (undivided) members (Maclay and Small, 1976). In the study area, the Edwards Group is typically about $400 \mathrm{ft}$ thick.

The Kainer Formation is composed of (in increasing abundance) shale, dolomite, chert, packstone, grainstone, miliolid grainstone, wackestone, and mudstone. Chert is found throughout the formation. The Person Formation is composed of (in increasing abundance) shale, grainstone, miliolid grainstone, wackestone, packstone, and mudstone. The Person Formation contains chert throughout. Descriptions of each of the geologic units with associated lithology and ichnofossils are shown in table 1. For additional geologic and ichnofossil descriptions, see Clark and others (2016).

\section{Faulting}

The principal structural feature in Hays and Comal Counties is the Balcones fault zone, which is the result of Miocene faulting (Weeks, 1945) and fracturing (fig. 1). As is typical elsewhere in the Balcones fault zone, most of the faults in the study area are high-angle to vertical, en echelon, normal faults, that are downthrown to the southeast (George, 1952). As with any normal fault extensional system, this also includes horst and graben structures (Pantea and others, 2014).

The primary orientation of mapped fractures and faults in the study area is southwest to northeast between 45 and 50 degrees azimuth. The secondary fractures trend obliquely to the Balcones fault zone at approximately $145-150$ degrees azimuth. Variations in strikes and dips of the faults in the outcrop result from stress-strain relations between the different lithologies (Trudgill, 2002; Ferrill and others, 2003; Clark and others, 2014).

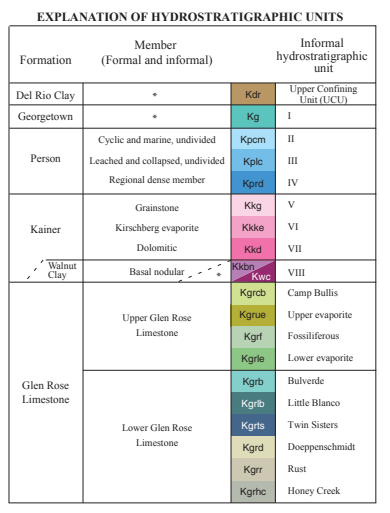

\section{Hydrostratigraphy}

Hydrostratigraphically, the rocks exposed in the study area represent a section of the Edwards aquifer, the upper zone of the Trinity aquifer, and the middle zone of the Trinity aquifer (table 1). In the study area, the Edwards aquifer yields water from rocks of the Edwards Group and the Trinity aquifer is formed in rocks of the Trinity Group. The Edwards and Trinity aquifers are 


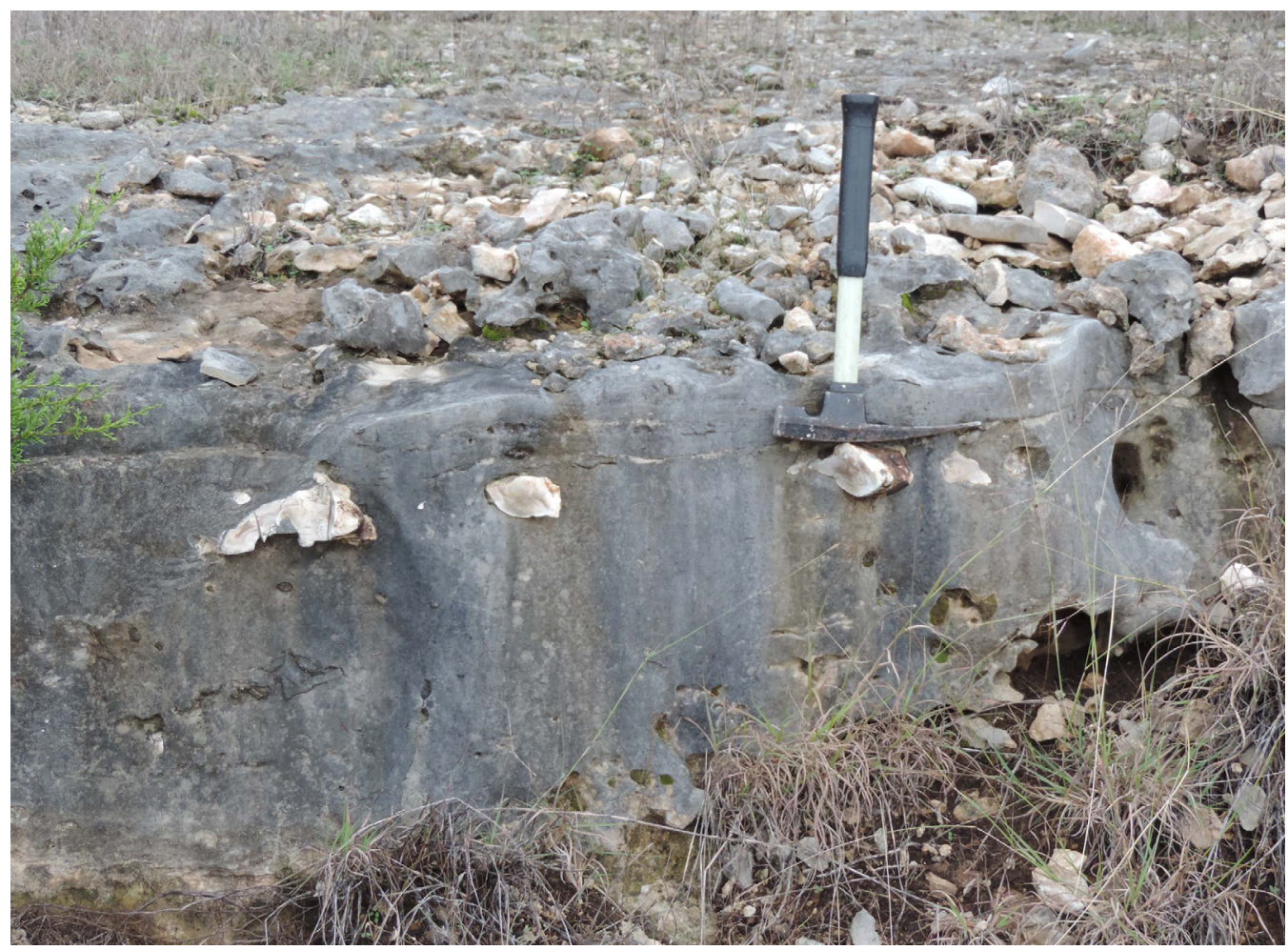

Figure 3. Photograph showing chert nodules in the dolomitic member of the Kainer Formation. The photograph also shows vug and moldic porosity.

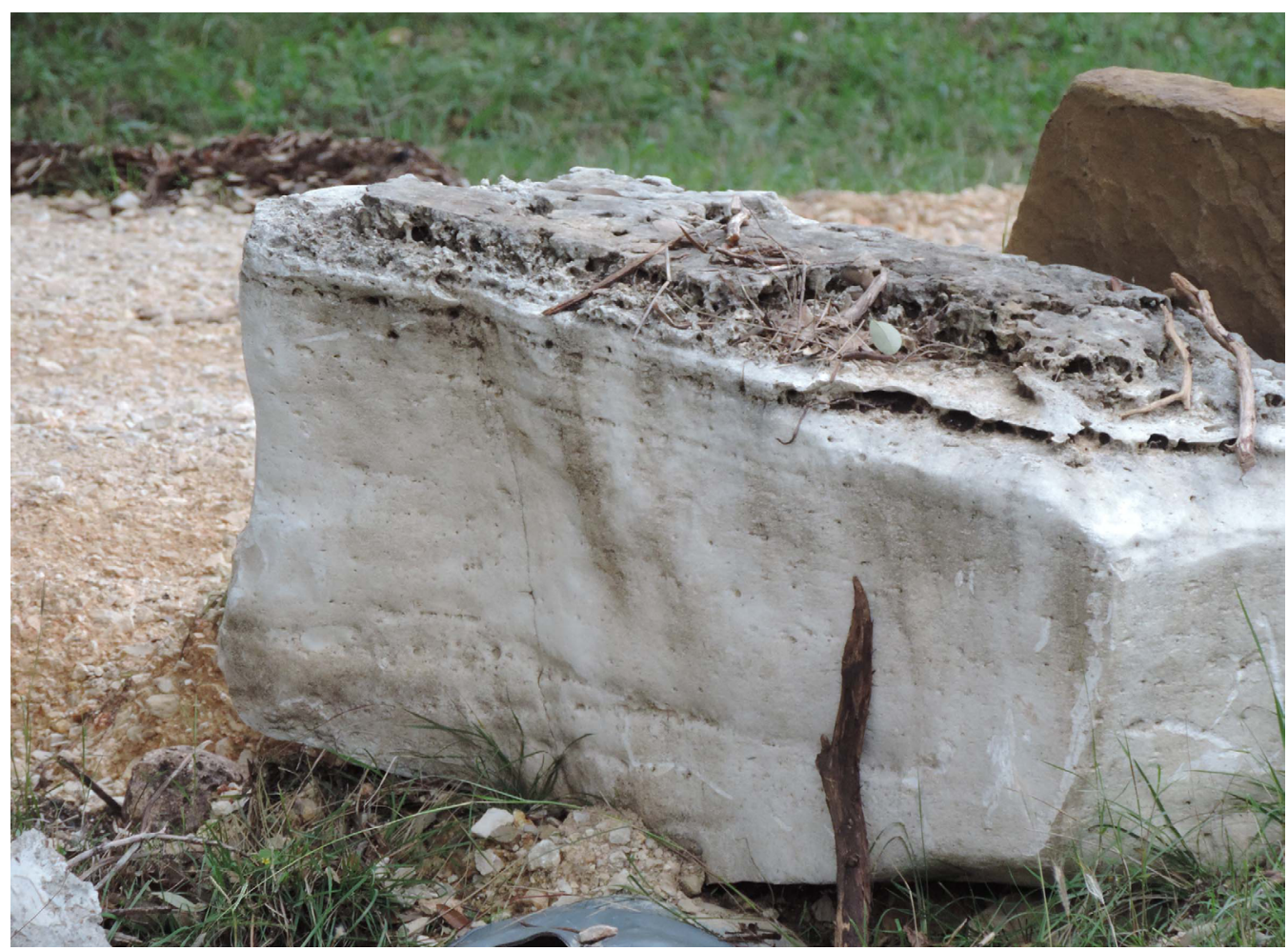

Figure 4. Photograph showing laminations in the grainstone member of the Kainer Formation, some fenestral porosity near the top of the boulder. The thickness of the gray boulder is approximately $60 \mathrm{~cm}$. 


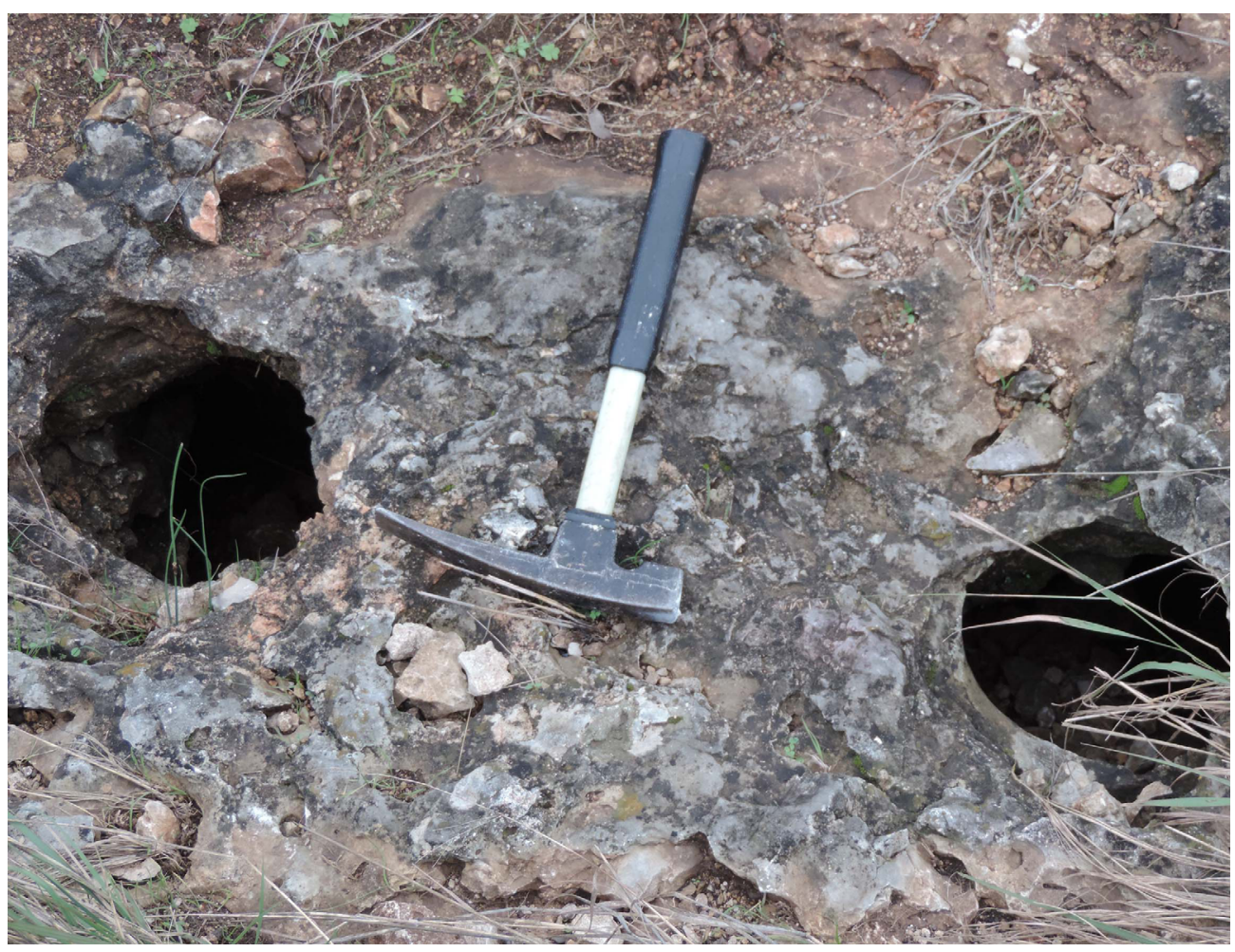

Figure 5. Photograph showing solution channels (to the left and right of the hammer) in the hydrostratigraphic units VIII (basal nodular member/Walnut Clay).

karstic with high secondary porosity that is developed along bedding and fractures (Maclay and Small, 1983; Johnson and others, 2002; Ferrill and others, 2003; Gary and others, 2011). The descriptions of the hydrostratigraphy and porosity of individual (HSUs) shown on figure 2 are modified and expanded from Choquette and Pray (1970), Maclay and Small (1976), Stein and Ozuna (1995), Clark and others (2009), Blome and Clark (2014), Clark and Morris (2015), and Clark and others (2016). For additional descriptions of the upper confining unit, Edwards aquifer, and Trinity aquifer see Clark and others (2016).

The Del Rio Clay is a confining unit above the Edwards aquifer and does not supply appreciable amounts of water to wells in the study area (fig. 2). Because the formation is a confining unit and not water-bearing, it will not be discussed further in this report.

\section{Edwards Aquifer}

The Edwards aquifer was subdivided into HSUs I to VIII by Maclay and Small (1976) (fig. 2). The Georgetown Formation of the Washita Group contains HSU I. The Person Formation of the Edwards Group contains HSUs II (cyclic and marine members [undivided]), III (leached and collapsed members [undivided]), and IV (regional dense member); the Kainer Formation of the Edwards Group contains HSUs V (grainstone member), VI (Kirschberg evaporite member), VII (dolomitic member), and VIII (basal nodular member/Walnut Clay) (fig. 6).

\section{Trinity Aquifer}

Ashworth (1983) subdivided the Trinity aquifer into upper, middle, and lower aquifer units (zones) (fig. 2). The upper zone of the Trinity aquifer yields water from the upper member of the Glen Rose Limestone. The middle zone of the Trinity aquifer yields water from the lower member of the Glen Rose Limestone, the Hensell Sand, and the Cow Creek Limestone. The latter two formations are not exposed in the field area. The regionally extensive Hammett Shale forms a confining unit between the middle and lower zones of the Trinity aquifer. The Hammett Shale and the lower zone of the Trinity aquifer, which consists of the Sligo and Hosston Formations, do not crop out in the study area.

\section{Upper Zone of the Trinity Aquifer}

The upper zone of the Trinity aquifer was informally subdivided into five HSUs in Bexar County (fig. 2) by Clark (2003) and was subsequently renamed (informally) by Clark and others (2009). In the study area, however, there are only three HSUs present (top to bottom): the Camp Bullis, fossiliferous (fig.6), and lower evaporite. 


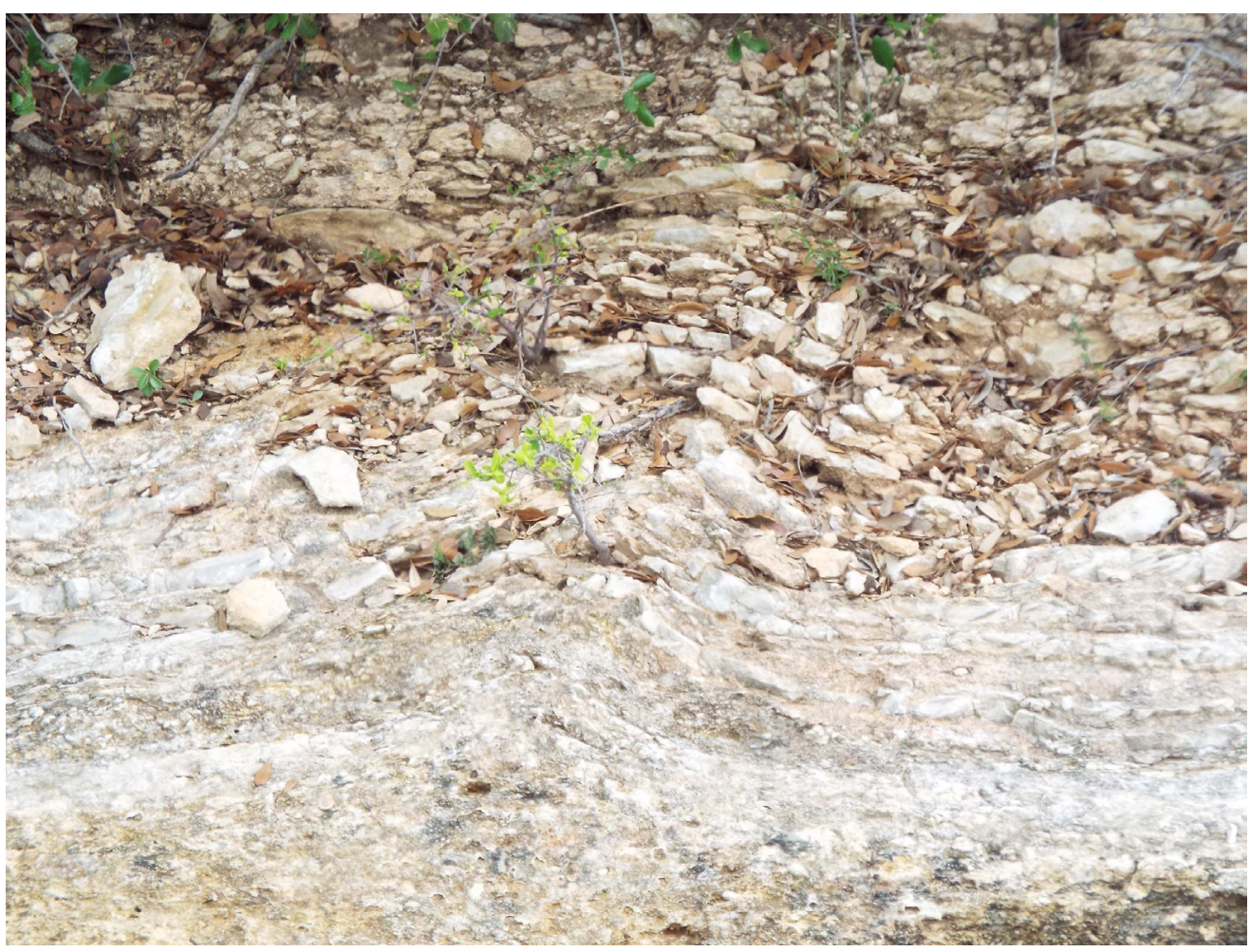

Figure 6. Photograph of tepee structures at the base of the fossiliferous hydrostratigraphic units. The laminations are approximately $3 \mathrm{~cm}$ thick.

\section{Middle Zone of the Trinity Aquifer}

The middle zone of the Trinity aquifer is composed of the Bulverde, Little Blanco, Twin Sisters, Doeppenschmidt, Rust, Honey Creek, Hensell, and Cow Creek HSUs (Clark and Morris, 2015) (fig. 2). Underlying the Cow Creek is the regional confining unit, the Hammett HSU, which separates the middle and lower zones of the Trinity aquifer. In the study area, only the Bulverde, Little Blanco, Twin Sisters, Doeppenschmidt, Rust, and Honey Creek crop out. The lower zone of the Trinity aquifer does not crop out in the study area.

\section{Hydrologic Characteristics of Structure}

From field observations and previous studies, it is apparent that the hydrologic connection between the Edwards and Trinity aquifers and the various HSUs is complex. The source of complexity in the aquifer system results from a combination of the original depositional history, bioturbation, primary and secondary porosity, diagenesis, and fracturing of the area from faulting. All of these factors have resulted in the development of modified porosity, permeability, and transmissivity within and between the aquifers. The original depositional sediments have produced lithified layers of shales, impure limestones, and limestones which in turn have varying types of porosity related to biological activity and to subsequent diagenesis.
Faulting has produced highly fractured areas that have allowed for the rapid infiltration of water and subsequently formed solutionally enhanced fractures, bedding planes, channels, and caves that are highly permeable and transmissive. The juxtaposition of the aquifers and HSUs due to faulting has resulted in areas of interconnectedness between the Edwards and Trinity aquifers and the various HSUs that form the aquifers. For additional descriptions of how structure potentially affects the local hydrogeology, see Clark and others (2016).

\section{Summary}

The Edwards and Trinity aquifers are major sources of water in south-central Texas and are both classified as major aquifers by the State of Texas. The population of the central Texas area in Hays and Comal Counties is rapidly growing, increasing demands on the area's water resources. To help effectively manage the water resources in the area, refined maps and descriptions of the geologic structures and HSUs of the aquifers in the Driftwood and Wimberley 7.5-minute quadrangles in Hays and Comal Counties, Tex., are needed.

The purpose of this report is to present the geology and hydrostratigraphy of the Driftwood and Wimberley 7.5-minute quadrangles in Hays and Comal Counties, Tex., as a detailed 1:24,000-scale hydrostratigraphic map with names and 
descriptions of the geologic and hydrostratigraphic units in the study area. The report includes the approximately 128 square miles $\left(\mathrm{mi}^{2}\right)$ within the outcrops of the Edwards and Trinity aquifers in the Driftwood and Wimberley 7.5-minute quadrangles in Hays and Comal Counties, Tex.

The rocks within the study area are karstic, sedimentary, and range in age from Early to Late Cretaceous. Karstic areas are characterized by sinkholes, caves, and underground streams that result in rapid recharge of surface waters infiltrating into the subsurface and rapidly flowing through entrenched groundwater flowpaths. Lower Cretaceous rocks include the Trinity and Edwards Groups, and Upper Cretaceous rocks include the Georgetown Formation of the Washita Group.

The Trinity Group contains shale, mudstone to grainstone, boundstone, evaporites, sandstone, and argillaceous limestone and in this study area is represented by the Hosston Formation, Sligo Formation, Hammett Shale, Cow Creek Limestone, Hensell Sand, and Glen Rose Limestone The Hosston, Sligo, Hammett Shale, Cow Creek Limestone, Hensell Sand Formations of the Trinity Group are not present in surface exposures in the study area.

The Edwards Group, which overlies the Trinity Group, is composed of shale, dolomite, chert, evaporites, packstone, grainstone, miliolid grainstone, wackestone, and mudstone. In the study area, the Edwards Group is composed of the Kainer and Person Formations. The Kainer Formation is subdivided into the following informal (bottom to top) the basal nodular/ Walnut Clay, dolomitic, Kirschberg evaporite, and grainstone. The Person Formation is subdivided into the following informal units (bottom to top): (1) the regional dense, (2) leached and collapsed (undivided), and (3) cyclic and marine (undivided) members.

The Miocene Balcones fault zone is the primary structural feature within the study area and is an extensional system of faults that generally trends southwest to northeast across south-central Texas. The faults are vertical to near-vertical with normal throw, are en echelon, and are mostly downthrown to the southeast.

Hydrostratigraphically, the rocks exposed in the study area represent a section of the upper confining unit to the Edwards aquifer, the Edwards aquifer, the upper zone of the Trinity aquifer, and the middle zone of the Trinity aquifer. In the study area the Edwards aquifer is composed of the Georgetown Formation and of the rocks forming the Edwards Group. The Trinity aquifer is composed of the rocks forming the Trinity Group. The Edwards and Trinity aquifers are karstic with high secondary porosity along bedding and fractures. The Del Rio Clay is a confining unit above the Edwards aquifer and does not supply appreciable amounts of water to wells in the study area.

The Edwards aquifer was subdivided into HSUs I to VIII. The Georgetown Formation of the Washita Group contains HSU I. The Person Formation of the Edwards Group contains HSU units II (cyclic and marine members [undivided]),
III (leached and collapsed members [undivided]), and IV (regional dense member); the Kainer Formation of the Edwards Group contains hydrostratigraphic units V (grainstone member), VI (Kirschberg evaporite member), VII (dolomitic member), and VIII (basal nodular member/Walnut Clay).

The Trinity aquifer is separated into upper, middle, and lower aquifer units (zones). The upper zone of the Trinity aquifer is in the upper member of the Glen Rose Limestone. The middle zone of the Trinity aquifer is formed in the lower member of the Glen Rose Limestone, Hensell Sand, and Cow Creek Limestone. The regionally extensive Hammett Shale forms a confining unit between the middle and lower zones of the Trinity aquifer. The Hammett Shale and the lower zone of the Trinity aquifer, which consists of the Sligo and Hosston Formations, do not crop out in the study area.

The upper zone of the Trinity aquifer was first informally subdivided into five hydrostratigraphic units in Bexar County. In the study area, however, only three HSUs are present (top to bottom): the Camp Bullis, fossiliferous, and lower evaporite. The middle zone of the Trinity aquifer originally was informally subdivided into nine HSUs in Bexar and Comal Counties, but, only the Bulverde, Little Blanco, Twin Sisters, Doeppenschmidt, Rust, and Honey Creek are present in outcrop in the study area.

From field observations and previous studies, the hydrologic connection between the Edwards and Trinity aquifers and the various HSUs is complex. The source of complexity in the aquifer system is a combination of the original depositional history, bioturbation, primary and secondary porosity, diagenesis, and fracturing of the area from faulting. All of these factors have resulted in the development of modified porosity, permeability, and transmissivity within and between the aquifers. The original depositional sediments have produced layers of shales, impure limestones, and limestones that in turn have varying types of porosity related to biological activity and to subsequent diagenesis. Faulting has resulted in highly fractured areas that have allowed for the rapid infiltration of water and subsequently formed solutionally enhanced fractures, bedding planes, channels, and caves which are highly permeable and transmissive. The juxtaposition of the aquifers and hydrostratigraphic units because of faulting has resulted in areas of interconnectedness between the Edwards and Trinity aquifers and the various hydrostratigraphic units that form the aquifers.

\section{Acknowledgments}

The authors would like to recognize the landowners and managers of private and public lands in Hays and Comal Counties, Texas, who provided access to their property for this study. 


\section{References Cited}

Amsbury, D.L., 1974, Stratigraphic petrology of lower and middle Trinity rocks on the San Marcos platform, SouthCentral Texas, in Aspects of Trinity Geology: Geoscience and Man, v. 8, p. 1-35.

Ashworth, J.B., 1983, Ground-water availability of the Lower Cretaceous formations in the Hill Country of south-central Texas: Texas Department of Water Resources Report 273, 172 p. [Also available at http://eahcp.org/documents/1983 Ashworth_GroundWaterAvailability.pdf.]

Barker, R.A., and Ardis, A.F., 1996, Hydrogeological framework of the Edwards-Trinity aquifer system, west-central Texas: U.S. Geological Survey Professional Paper 1421-B, 61 p. [Also available at http://pubs.er.usgs.gov/publication/ pp1421B.]

Barnes, V.E., 1976, Geologic atlas of Texas, Crystal CityEagle Pass sheets, Dolan Hoye Eargle memorial edition: Austin, University of Texas-Austin, Bureau of Economic Geology, 1 sheet, scale 1:250,000.

Blome, C.D., and Clark, A.K., 2014, Key subsurface data help to refine Trinity aquifer hydrostratigraphic units, southcentral Texas: U.S. Geological Survey Data Series 768, 1 sheet, http://dx.doi.org/10.3133/ds768.

Choquette, P.W., and Pray, L.C., 1970, Geologic nomenclature and classification of porosity in sedimentary carbonates: American Association of Petroleum Geologists Bulletin, v. 54 , no. 2 , p. $207-250$.

Clark, A.K., 2003, Geologic framework and hydrogeologic features of the Glen Rose Limestone, Camp Bullis Training Site, Bexar County, Texas: U.S. Geological Survey Water-Resources Investigations Report 03-4081, 9 p., 1 pl., scale 1:24,000, https://pubs.usgs.gov/wri/wri034081/.

Clark, A.K., 2004, Geologic framework and hydrogeologic characteristics of the Glen Rose Limestone, Camp Stanley Storage Activity, Bexar County, Texas: U.S. Geological Survey Scientific Investigations Map 2831, scale 1:24,000, 1 p., 1 pl. [Also available at http://pubs.usgs.gov/ $\operatorname{sim} / 2005 / 2831 / \mathrm{pdf} / \operatorname{sim} 2831$.pdf.]

Clark, A.R., Blome, C.D., and Faith, J.R., 2009, Map showing the geology and hydrostratigraphy of the Edwards aquifer catchment area, northern Bexar County, south-central Texas: U.S. Geological Survey OpenFile Report 2009-1008, 24 p., 1 pl., scale 1:50,000, http://pubs.usgs.gov/of/2009/1008/.
Clark, A.K., Faith, J.R., Blome, C.D., and Pedraza, D.E., 2006, Geologic map of the Edwards aquifer in northern Medina and northeastern Uvalde Counties, south-central Texas: U.S. Geological Survey Open-File Report 20061372, 23 p., 1 pl., https://pubs.er.usgs.gov/publication/ ofr20061372.

Clark, A.K., Pedraza, D.E., and Morris, R.R., 2013, Geologic framework, structure, and hydrogeologic characteristics of the Knippa Gap area in eastern Uvalde and western Medina Counties, Texas: U.S. Geological Survey Scientific Investigations Report 2013-5149, 35 p., 1 pl., http://pubs.usgs.gov/sir/2013/5149/.

Clark, A.K., Blome, C.D., and Morris, R.R., 2014, Geologic framework and hydrostratigraphy of Guadalupe River State Park and Honey Creek State Natural Area, Kendall and Comal Counties, Texas: U.S. Geological Survey Scientific Investigations Map 3303, 8 p., 1 sheet, scale 1:24,000, http://dx.doi.org/10.3133/sim3303.

Clark, A.K., and Morris, R.R., 2015, Geologic and hydrostratigraphic map of the Anhalt, Fischer, and Spring Branch 7.5-minute quadrangles, Blanco, Comal, and Kendall Counties, Texas: U.S. Geological Survey Scientific Investigations Map 3333, 13 p., 1 sheet, scale 1:50,000. [Also available at http://dx.doi.org/10.3133/sim3333.]

Clark, A.K., Golab, J.A., and Morris, R.R., 2016, Geologic framework, hydrostratigraphy, and ichnology of the Blanco, Payton, and Rough Hollow 7.5-minute quadrangles, Blanco, Comal, Hays, and Kendall Counties, Texas: U.S. Geological Survey Scientific Investigations Map 3363, 21 p., 1 sheet, scale 1:24,000, http://dx.doi.org/10.3133/sim3363.

Douglas, R.C., 1960, The foraminiferal genus Orbitolina in North America: U.S. Geological Survey Professional Paper 333, $52 \mathrm{p}$.

Dunham, R.J., 1962, Classification of carbonate rocks according to depositional texture, in Ham, W.E., Classification of carbonate rocks symposium: American Association of Petroleum Geologists Memoir 1, p. 108-121.

Esri, 2016, ArcGIS Desktop—Release 10: Esri, Redlands, Calif. [Also available at http://www.esri.com.]

Ferrill, D.A., Sims, D.W., Morris, A.P., Waiting, D.J., and Franklin, N.M., 2003, Structural controls on the Edwards aquifer/Trinity aquifer interface in the Camp Bullis quadrangle, Texas: Edwards Aquifer Authority and U.S. Army Corps of Engineers, prepared by Southwest Research Institute, San Antonio, Tex., variously paged, accessed June 5, 2013, at http://data.edwardsaquifer.org/files/SWRI_Camp_ Bull_Rpt.pdf. 
Gary, Marcus, Veni, George, Shade, Beverly, and Gary, Robin, 2011, Spatial and temporal recharge variability related to groundwater interconnection of the Edwards and Trinity aquifers, Camp Bullis, Bexar and Comal Counties, Texas; in Gary, M.O., Gary, R.H., and Hunt, B.B, eds., Interconnection of the Trinity (Glen Rose) and Edwards aquifers along the Balcones fault zone and related topics, Austin, Tex., February 17, 2011, Proceedings: Karst Conservation Initiative , p. 6-10, accessed on February 9, 2016 at, http://www.bseacd.org/uploads/ AquiferScience/Proceedings_Edwards_Trinity final.pdf.

George, P.G., Mace, R.E., and Petrossian, Rima, 2011, Aquifers of Texas: Texas Water Development Board Report 380, Austin, Tex., $172 \mathrm{p}$.

George, W.O., 1952, Geology and ground-water resources of Comal County, Texas, with sections on surface-water supplies and chemical character of the water, with a section by Breeding, S.D., and Hastings, W.W.: U.S. Geological Survey Water Supply Paper 1138, Report: vi, 126 p., 3 pl. [Also available at https://pubs.er.usgs.gov/publication/wsp1138.]

Hanson, J.A., and Small, T.A., 1995, Geologic framework and hydrogeologic characteristics of the Edwards aquifer outcrop, Hays and Comal Counties, Texas: U.S. Geological Survey Water-Resources Investigations Report 95-4265, $10 \mathrm{p}$.

Hantzschel, Walter, 1962, Trace fossils and problematica, in Moore, R.C., ed., Treatise on invertebrate paleontologyPart W, Miscellanea: Geological Society of America and University of Kansas Press, p. W177-W245.

Hasiotis, S.T., and Mitchell, C.E., 1993, A comparison of crayfish burrow morphologies-Triassic and Holocene fossil, paleo- and neo-ichnological evidence, and the identification of their burrowing signatures: Ichnos, v. 2, p. 291-314.

Hill, R.T., 1891, The Comanche Series of the Texas-Arkansas Region: Geological Society of America Bulletin 2, p. 503-528.

Hill, R.T., 1900, Physical geography of the Texas region: U.S. Geological Survey, Topographic atlas of the United States, folio 3.

Hill, R.T., 1901, Geography and geology of the Black and Grand prairies, Texas, with detailed descriptions of the Cretaceous formations and special reference to artesian waters, in Walcott, C.D., ed., Twenty-first annual report of the United States Geological Survey to the Secretary of the Interior, 1899-1900-Part VII; Texas, U.S. Geological Survey Annual Report 21.

Imlay, R.W., 1940, Lower Cretaceous and Jurassic formation of southern Arkansas and their oil and gas possibilities: Arkansas Geological Survey Information Circular, no. 12, $64 \mathrm{p}$.
Imlay, R.W., 1945, Subsurface Lower Cretaceous formations of south Texas: American Association of Petroleum Geologists Bulletin, v. 29, no. 10, p. 1416-1469.

Inden, R.F., 1974, Lithofacies and depositional model for a Trinity Cretaceous sequence, central Texas, in Perkins, B.F., and Amsbury, D.L., eds., Aspects of Trinity Geology: Geoscience and Man, v. 8, p. 37-52.

Johnson, Steve, Esquilin, Roberto, Mahula, David, Thompson, Emily, Mireles, Jesse, Gloyd, Ron, Sterzenback, Joseph, Hoyt, John, and Schindel, Geary, 2002, Hydrogeologic data report for 2001: Edwards Aquifer Authority, p. 1-3.

Kuniansky, E.L., and Ardis, A.F., 1997, Hydrogeology and ground-water flow in the Edwards-Trinity aquifer system, west-central Texas - Regional aquifer-system analysisEdwards-Trinity: U.S. Geological Survey Professional Paper 1421-C, 78 p. [Also available at https://pubs.er.usgs.gov/ publication/pp1421C.]

Lozo, F.E., and Stricklin, F.L., Jr., 1956, Stratigraphic notes on the outcrop basal Cretaceous, central Texas: Gulf Coast Association of Geological Societies transactions, v. 6, p. 67-78.

Maclay, R.W., and Small, T.A., 1976, Progress report on geology of the Edwards aquifer, San Antonio area, Texas, and preliminary interpretation of borehole geophysical and laboratory data on carbonate rocks: U.S. Geological Survey Open-File Report 76-627, 65 p. [Also available at https://pubs.er.usgs.gov/publication/ofr76627.]

Maclay, R.W., and Small, T.A., 1983, Hydrostratigraphic subdivisions and fault barriers of the Edwards aquifer, southcentral Texas: Journal of Hydrology, v. 61, p. 127-146.

Maclay, R.W., and Small, T.A., 1986, Carbonate geology and hydrology of the Edwards aquifer in the San Antonio Area, Texas: Texas Water Development Board, Report 296, 90 p.

Pantea, M.P., Blome, C.D., and Clark, A.K., 2014, Threedimensional model of the hydrostratigraphy and structure of the area in and around the U.S. Army-Camp Stanley Storage Activity Area, northern Bexar County, Texas: U.S. Geological Survey Scientific Investigations Report 2014-5074, 13 p., https://doi.org/10.3133/sir20145074.

Pemberton, S.G., and Frey, R.W., 1982, Trace fossil nomenclature and the planolites-paleophycus Dilemma: Journal of Paleontology, v. 56, no. 4, p. 843-881.

Perkins, B.F., 1974, Paleoecology of a rudist reef complex in the Comanche Cretaceous Glen Rose Limestone of central Texas, in Aspects of Trinity Geology: Geoscience and Man, v. 8, p. 131-173. 
Richardson, G.B., 1904, Report of a reconnaissance in TransPecos Texas north of the Texas and Pacific Railway: University of Texas, Mineral Survey Bulletin, no. 9, 119 p.

Roemer, F.v., 1852, Die Kriedebildungen von Texas and ihre organischen Einschlusse Usse: Bonn, Germany, 100 p., $11 \mathrm{pl}$.

Rose, P.R., 1972, Edwards Group, surface and subsurface, central Texas: Austin, University of Texas, Bureau of Economic Geology Report of Investigations 74, 198 p.

Ryan, Martin, and Meiman, Joe, 1996, An examination of short-term variations in water quality at a karst spring in Kentucky: Ground Water, v. 34, p. 23-30.

Stein, W.G., and Ozuna, G.B., 1995, Geologic framework and hydrogeologic characteristics of the Edwards Aquifer recharge zone, Bexar County, Texas: U.S. Geological Survey Water-Resources Investigations Report 95-4030, 8 p. [Also available https://pubs.er.usgs.gov/publication/ wri954030.]

Stricklin, F.L., Jr., Smith, C.I., and Lozo, F.E., 1971, Stratigraphy of Lower Cretaceous Trinity deposits of central Texas: University of Texas at Austin, Bureau of Economic Geology Report of Investigations 71, 63 p.

Stricklin, F.L., Jr., and Smith, C.I., 1973, Environmental reconstruction of a carbonate beach complex, Cow Creek (Lower Cretaceous) Formation of Central Texas: Geological Society of America Bulletin, v. 84, no. 4, p. 1349-1367.
Trudgill, B.D., 2002, Structural controls on drainage development in the Canyonlands grabens of southeast Utah, USA, in Underhill, J.R., and Trudgill, B.D., eds., The structure and stratigraphy of rift systems: American Association of Petroleum Geologists Bulletin Special Issue, v. 86, no. 6, p. 1095-1112.

U.S. Census Bureau, 2016, Five of the Nation's eleven fastest-growing cities are in Texas, Census Bureau Reports: U.S. Census Bureau, release no. CB16-81, accessed July 12, 2016, at http://www.census.gov/newsroom/ press-releases/2016/cb16-81.html.

U.S. Geological Survey, 2011, What is karst: U.S. Geological Survey Groundwater Information website, accessed April 11, 2011, at http:/water.usgs.gov/ogw/karst/pages/ whatiskarst.

Weeks, A.W., 1945, Balcones, Luling and Mexia fault zones in Texas: American Association of Petroleum Geologists Bulletin, v. 29, p. 1733-1737.

Wierman, D.A., Broun, A.S., and Hunt, B.B., 2010, Hydrogeologic atlas of the Hill Country Trinity Aquifer, Blanco, Hays, and Travis Counties, central Texas: Hays-Trinity, Barton Springs/Edwards Aquifer, and Blanco-Pedernales Groundwater Conservation Districts, San Antonio, Tex., July 2010, 17 p.

Whitney, M.I., 1952, Some zone marker fossils of the Glen Rose Formation of central Texas: Journal of Paleontology, v. 26 , no. 1, p. $65-73$.

\author{
Publishing support provided by \\ Denver Publishing Service Center, Denver, Colorado \\ For more information concerning this publication, contact \\ Director, USGS Texas Water Science Center \\ 1505 Ferguson Lane \\ Austin, TX 78754-4733 \\ (512) 927-3590 \\ Or visit the Texas Science Center website at \\ https://tx.usgs.gov/ \\ This publication is available online at \\ https://doi.org/10.3133/sim3386
}





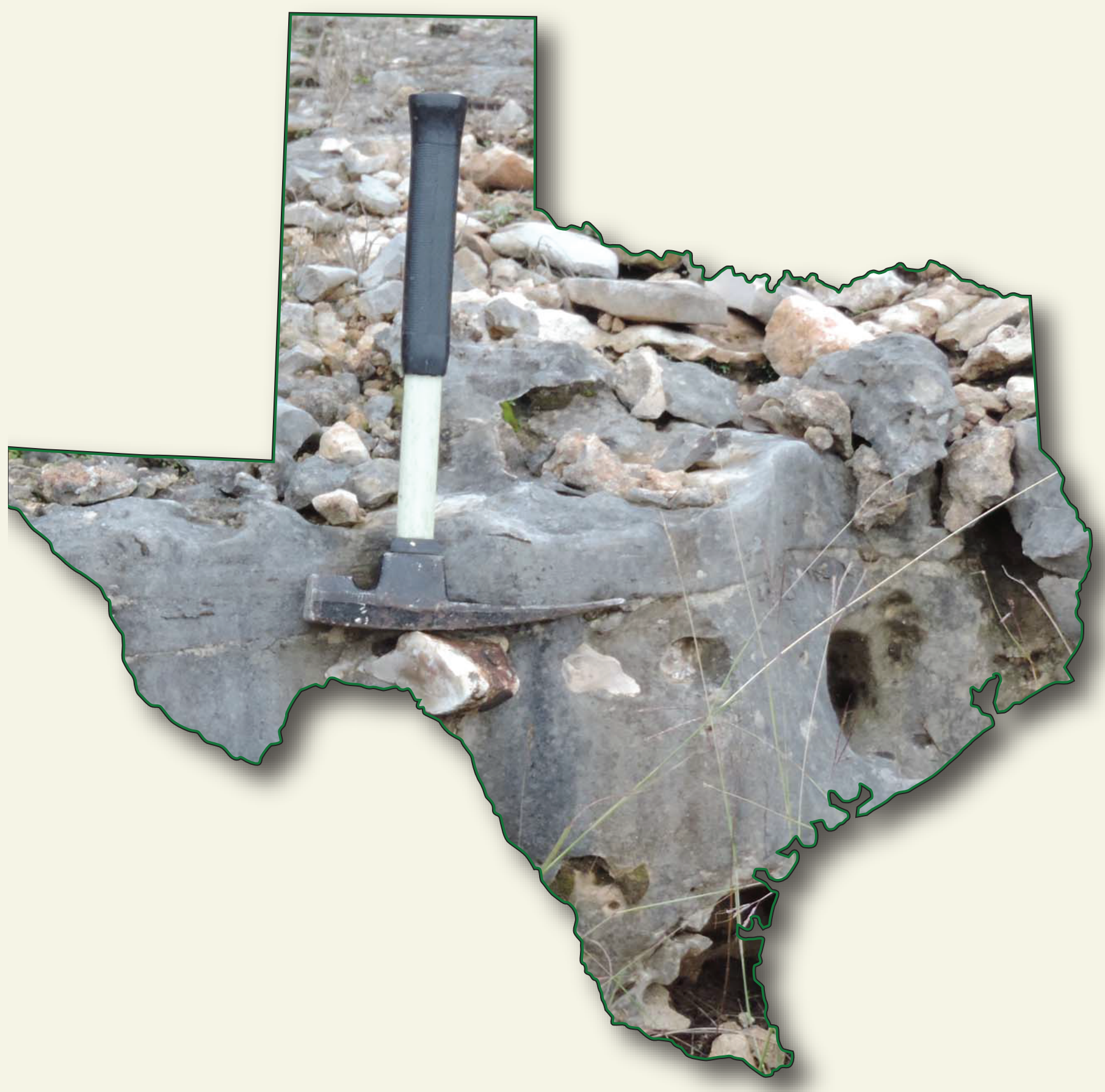

